\title{
Faculty Development Practices in Canadian Universities
}

\author{
ABRAM G. KONRAD*
}

\begin{abstract}
This article reports on a survey of faculty development practices in Canadian universities - the extent of their use and estimated effectiveness. Sixty percent of the universities had an organized program, although only 40 percent had a coordinator of development practices. Traditional practices, like sabbaticals, travel funds, and newsletters, were most common, although some of the least used practices were judged most effective. The most pressing faculty development needs were in instructional improvement, rather than in personal or organizational development. Participation in development activities was greatest among good teachers who wanted to get better, rather than among those who really needed to improve. For development programs to become more effective, it seems that institutional commitments for faculty development will have to be strengthened, both organizationally and financially.
\end{abstract}

\section{RÉSUMÉ}

Cet article rapporte les résultats d'une enquête traitant des politiques et pratiques de perfectionnement pédagogique et professionnel utilisées dans nos universités. Bien que $60 \%$ de ces universités aient des programmes organisés pour répondre aux besoins pédagogiques ou professionnels de la faculté, seulement $40 \% d$ 'entre elles avaient un coordonnateur. Les pratiques de perfectionnement traditionnelles telles que les congés d'étude, les fonds de voyage, et les publications étaient les plus communes, quoique les pratiques les moins utilisées étaient jugées les plus efficaces. Le besoin le plus pressant se situait dans le domaine du perfectionnement de l'instruction plutôt que dans celui du développement personnel ou structurel. Les meilleurs participants aux activités de perfectionnement furent les bons enseignants qui cherchaient a s'améliorer plutôt que les enseignants qui auraient eu besoin de cette même amélioration. Il s'avère important que nos institutions consolident leurs politiques de financement et d'organisation si l'on veut des programmes de perfectionnement pédagogique et professionnel plus efficaces.

* Centre for the Study of Postsecondary Education, University of Alberta, Edmonton, Alberta. 
Throughout the history of higher education, excellence has been recognized and pursued in various ways. Indeed, according to Professor Sheffield's (1974) research, there is no one way either to define or achieve excellence in university teaching. And the same generalization could undoubtedly apply as well to the research and service activities of professors.

Notwithstanding the complexity of professional roles, considerable thought and effort has focused upon the improvement of role performance in recent years. The heightened interest in improvement relates not only to the quest for personal excellence, but also to factors external to the professoriate. Webb and Smith (1976) identified the declining or steady state enrolments and the recruitment of minority students with special needs among the factors leading to increased interest in faculty development in the United States. The general disenchantment expressed by students, parents and legislators with the quality of instruction was cited by Centra (1976) as another factor. An increase in funding faculty development programs in Mexican universities was reported by Morales and McGinn (1982) as a way of appeasing university complaints related to a slowdown in funding.

Canadian higher education also experienced considerable retrenchment during the 1970's. Faculty became much less mobile and fewer appointments of new Ph.D.'s were made than in the previous decade. Universities could no longer depend upon changes in faculty as a means of acquiring new ideas. At the same time, increasing demands for accountability placed expectations of increased productivity upon available faculty. The advancement of educational technology constituted yet another factor leading to faculty development initiatives.

For at least a decade now, specific efforts have been made to facilitate the quest for excellence in Canadian higher education. In a survey of instructional improvement practices in Canadian colleges and universities, Shore (1974) described these practices as irregular and haphazard, offering only a limited range of services. Only 13 universities had formal offices or committees established for coordinating instructional improvement activities.

Of course, faculty development is more than instructional improvement. It concerns itself with a broad range of activities designed to assist faculty in the quest for excellence in their various roles. Its earlier emphasis, according to Centra (1976), was upon orientation of new faculty to an institution through precollege workshops, financial assistance to attend professional meetings, and occasional conferences on teaching. Jerry Gaff (1975) referred to staff development as faculty renewal - a reshaping process of the faculty. In Nelson's (1979; 142) view, this process includes "activities designed to improve faculty performance in all aspects of their professional lives - as teachers, scholars, and contributors to institutional decisions."

Perhaps the most comprehensive perspective on faculty development was offered by Bergquist and Phillips (1975). In their view, faculty development is comprised of three components: personal development, instructional improve- 
ment, and organizational development. Personal development activities focus upon attitude formation and include interpersonal skills training, career counseling, and other personal growth activities; instructional improvement activities include course design, curriculum development, instructional methodology and technology, evaluation and diagnosis, etc.; whereas organizational development concerns itself with structural and environmental factors such as team building and management training.

In this paper, faculty development will be viewed broadly to include all policies and practices designed to assist faculty members toward renewal and growth in their various roles. As Crow et al. (1976) point out, faculty development is the term most used in periodicals and at academic meetings to describe such growth experience.

\section{METHODOLOGY}

The survey reported in this paper was conducted during the 1981-82 academic year at the University of Alberta. The project was undertaken to describe faculty development activities in Canadian universities and to ascertain their perceived effectiveness. All public degree-granting institutions were included in the population.

A letter to the president of each university asked whether the institution had an organized program or a set of activities for faculty development. If it did, the name of the person coordinating the activities was also requested. Of the 50 universities which responded to this inquiry, thirty or 60 percent indicated they had such a program or a set of faculty development activities.

The second phase of the study consisted of surveying the "coordinators" of faculty development programs. A survey instrument, first used by John Centra (1976) in a study of faculty development practices in U.S. colleges and universities, was modified by the addition of three open-ended questions. The survey contained a listing of 45 developmental practices grouped in five categories: institution-wide practices; workshops, seminars, programs; media, technology, course development; analysis or assessment; and miscellaneous practices. These practices included activities designed to help faculty sharpen or update their skills as teachers, researchers, academic advisors and as professionals. For all but the institution-wide practices, respondents were asked to estimate the extent to which each practice was used at their institution and also to estimate its effectiveness as a development practice. The final section of the questionnaire elicited general information about faculty involvement in development activities, and the organization and funding of faculty development practices.

Questionnaires were mailed to thirty institutions identified in the presidential survey, and useable returns were received from twenty-five or 83 percent. The respondents held various offices, ranging from director of a development office (Director of Pedagogical Services) to chairperson of a faculty committee. In most 
instances, the respondent served on a part-time basis as coordinator of development activities.

\section{THE FINDINGS}

The primary purpose of this paper is to describe the nature and effectiveness of faculty development practices in Canadian universities as perceived by coordinators of such activities. Data are presented in tabular form by percentages based upon the return from 25 institutions. ${ }^{1}$ Responses on the 45 practices are reported in five major categories, followed by a discussion of the most pressing needs and most effective practices, and the organization and funding of faculty development practices.

\section{Institution-Wide Practices}

Many development practices assist faculty members individually or in small groups on a voluntary or invitational basis; some practices are designed to assist everyone alike on an institution-wide basis. Thirteen institution-wide practices are listed in Table 1, together with the percent of institutions at which the practice existed and the percent of respondents indicating the practice was effective, in order according to the frequency of their use in Canadian universities. These practices could be regarded as traditional practices, many being used widely for upgrading all faculty members.

Sabbatical leaves, travel funds to attend professional conferences, and the circulation of a newsletter or articles pertinent to faculty development were reported by more than 80 percent of the respondents. Only three practices were found at fewer than half of the universities.

The extent of use alone is not an adequate measure of the value of a practice. Respondents at institutions at which a practice existed were also asked to rate its effectiveness as a developmental practice. ${ }^{2}$ Only five practices were regarded as effective by more than 50 percent of the respondents; two of these were practices used by fewer than half of the institutions. Eighty percent of the respondents regarded setting aside a specific calendar period for professional development as an effective practice, although only about one-fourth of the institutions had such a practice. A temporary teaching load reduction to work on a new course, a major course revision, or research area was seen as effective by two-thirds of the respondents. About 60 percent regarded sabbatical leaves as an effective practice, and travel grants to refresh or update knowledge in a particular field was seen as effective by 56 percent.

${ }^{1}$ The research assistance of Peter Ngatia, a doctoral candidate in the administration of higher education at the University of Alberta, is gratefully acknowledged.

${ }^{2}$ A five-point scale of effectiveness was used: no idea of effectiveness, not very effective, somewhat effective, effective and very effective. In the text and tables "effective" includes the last two responses. 
17 Faculty Development Practices in Canadian Universities

\section{Table 1}

Use and Estimated Effectiveness of Institution-Wide Faculty Development Practices in Canadian Universities

\begin{tabular}{|c|c|c|}
\hline Practice & $\begin{array}{l}\text { Percent indicating } \\
\text { practice existed }\end{array}$ & $\begin{array}{l}\text { Percent indicating } \\
\text { practice effective }\end{array}$ \\
\hline $\begin{array}{l}\text { Sabbatical leaves with at least half } \\
\text { salary }\end{array}$ & 96 & 61 \\
\hline $\begin{array}{l}\text { Travel funds available to attend } \\
\text { professional conferences }\end{array}$ & 92 & 45 \\
\hline $\begin{array}{l}\text { Circulation of newsletter, articles, } \\
\text { etc. that are pertinent to teach- } \\
\text { ing improvement of faculty } \\
\text { development }\end{array}$ & 80 & 30 \\
\hline $\begin{array}{l}\text { Visiting scholars program that } \\
\text { brings people to the campus for } \\
\text { short or long periods }\end{array}$ & 72 & 28 \\
\hline $\begin{array}{l}\text { There is a campus committee on } \\
\text { faculty development }\end{array}$ & 68 & 19 \\
\hline $\begin{array}{l}\text { Travel grants to refresh or update } \\
\text { knowledge in a particular field }\end{array}$ & 64 & 56 \\
\hline $\begin{array}{l}\text { Temporary teaching load reductions } \\
\text { to work on a new course, major } \\
\text { course revision, or research area }\end{array}$ & 60 & 67 \\
\hline $\begin{array}{l}\text { A policy of unpaid leaves that } \\
\text { cover educational or develop- } \\
\text { mental purposes }\end{array}$ & 56 & 43 \\
\hline $\begin{array}{l}\text { There is a periodic review of the } \\
\text { performance of all faculty } \\
\text { members, whether tenured or not }\end{array}$ & 52 & 33 \\
\hline $\begin{array}{l}\text { Annual awards to faculty for } \\
\text { excellence in teaching }\end{array}$ & 52 & 25 \\
\hline $\begin{array}{l}\text { Summer grants for projects to } \\
\text { improve instruction or courses }\end{array}$ & 40 & 50 \\
\hline $\begin{array}{l}\text { A specific calendar period is set } \\
\text { aside for professional develop- } \\
\text { ment }\end{array}$ & 24 & 80 \\
\hline $\begin{array}{l}\text { Lighter than normal teaching load } \\
\text { for first year faculty }\end{array}$ & 20 & 49 \\
\hline
\end{tabular}

*Percent based only on institutions at which practice existed.

Among the least effective practices were a campus committee on faculty development, annual awards to faculty for excellence in teaching, a visiting scholars program, and the circulation of a newsletter or articles. Some practices, while ineffective for development purposes, may serve other important functions. Thus, annual awards and newsletters may raise the awareness level of faculty members for the perceived importance of an activity, but they may actually contribute little to the growth of an individual faculty member. 


\section{Workshops, Seminars, Programs}

Faculty development activities often are pursued through workshops, seminars or similar invitational programs. Participants usually volunteer on the basis of the topic under discussion. Sessions vary in length, ranging from a one-time twohour seminar, through a series of such seminars, to a weekend or even a weeklong intensive program.

Each of the ten topics, listed in Table $2^{3}$ in order according to the percent indicating its use by over 20 percent of the faculty members, was used in Canadian universities. Workshops dealing with instructional techniques, testing, and new or different curricular approaches were among the best attended and most effective. Although workshops on faculty affective development, academic advising, and management of departmental operations were not used frequently, they were perceived to be quite effective as development practices.

The workshops perceived to be least effective were on institutional goals and types of students enrolled, research and scholarship skills, and general issues or trends in education. In planning workshops, the needs and interests of faculty members should be paramount. As Centra (1976) pointed out, workshops should deal not with generalities, but rather with topics that have the potential of providing help to individual participants.

\section{Media, Technology, Course Development}

This group of seven practices, also reported in Table 2, involves the use of specialists or specialized services in providing assistance to faculty members individually.

All universities provided assistance in using audiovisual aids, and 44 percent of the respondents indicated that over 20 percent of the faculty members used this service at their institution. Other areas of frequent assistance included using instructional technology, developing teaching skills, and constructing tests. Most of the practices in this group were rated as moderately effective.

Providing simulated procedures which enable faculty to learn and practise specific teaching skills were rated highest in effectiveness $(63 \%)$, although 36 percent of the institutions had not used this practice.

\section{Analysis or Assessment}

Analysis or assessment practices ideally provide feedback to the faculty member that may serve as the basis for undertaking development activities. Diagnosis without assistance may leave the faculty member somewhat frustrated. Of course, many, faculty members are quite capable of structuring their own development plans, given a supportive institutional climate.

\footnotetext{
${ }^{3}$ A five-point scale of approximate use was used: not used, used by fewer than 5 percent, used $5-20$ percent, used by $20-50$ percent, used by over 50 percent. Table entries show percent not used, and combine the last two categories in to over 20 percent.
} 
19 Faculty Development Practices in Canadian Universities

\section{Table 2}

Estimated Use and Effectiveness of Faculty Development Practices: Workshops, Seminars, Programs and Media, Technology, Course Development

\begin{tabular}{|c|c|c|c|}
\hline Practice & $\begin{array}{l}\text { Percent ir } \\
\text { Not used }\end{array}$ & $\begin{array}{c}\text { ndicating use } \\
\text { Over } 20 \% \\
\end{array}$ & $\begin{array}{l}\text { Percent indicating } \\
\text { nractice effective* }\end{array}$ \\
\hline \multicolumn{4}{|l|}{ Workshops, seminars, programs -- } \\
\hline $\begin{array}{l}\text { That explore various methods or } \\
\text { techniques of instruction }\end{array}$ & 0 & 28 & 52 \\
\hline $\begin{array}{l}\text { On testing and evaluating } \\
\text { student performance }\end{array}$ & 16 & 20 & 56 \\
\hline $\begin{array}{l}\text { Dealing with new or different } \\
\text { approaches to develop } \\
\text { curricula }\end{array}$ & 16 & 16 & 60 \\
\hline $\begin{array}{l}\text { That explore general issues } \\
\text { or trends in education }\end{array}$ & 20 & 12 & 29 \\
\hline $\begin{array}{l}\text { That review subject matter or } \\
\text { introduce new knowledge }\end{array}$ & 24 & 8 & 33 \\
\hline $\begin{array}{l}\text { To acquaint faculty with goals } \\
\text { of the institution and types } \\
\text { of students enrolled }\end{array}$ & 32 & 8 & 23 \\
\hline $\begin{array}{l}\text { To help faculty improve their } \\
\text { research and scholarship } \\
\text { skills }\end{array}$ & 40 & 8 & 25 \\
\hline In faculty affective development & 24 & 4 & 54 \\
\hline $\begin{array}{l}\text { To help faculty improve their } \\
\text { academic advising and } \\
\text { counseling skills }\end{array}$ & 36 & 4 & 44 \\
\hline $\begin{array}{l}\text { To improve the management of } \\
\text { departmental operations }\end{array}$ & 20 & 0 & 39 \\
\hline \multicolumn{4}{|l|}{$\frac{\text { Media, technology, course }}{\text { development assistance in }}$} \\
\hline $\begin{array}{l}\text { Using audiovisual aids, in- } \\
\text { cluding closed-circuit TV }\end{array}$ & 0 & 44 & 49 \\
\hline $\begin{array}{l}\text { Using instructional technology } \\
\text { as a teaching aid }\end{array}$ & 20 & 16 & 27 \\
\hline $\begin{array}{l}\text { Developing teaching skills such } \\
\text { as lecturing, leading } \\
\text { discussions, or using } \\
\text { different teaching-learning } \\
\text { strategies }\end{array}$ & 20 & 12 & 54 \\
\hline $\begin{array}{l}\text { Constructing tests or evaluat- } \\
\text { ing student performance }\end{array}$ & 24 & 12 & 46 \\
\hline $\begin{array}{l}\text { Developing a course by consult- } \\
\text { ing on course objectives and } \\
\text { design }\end{array}$ & 12 & 8 & 47 \\
\hline $\begin{array}{l}\text { Providing a professional } \\
\text { library dealing with } \\
\text { instructional methodology, } \\
\text { teaching skills, psychology } \\
\text { of learning etc. }\end{array}$ & 12 & 8 & 38 \\
\hline $\begin{array}{l}\text { Providing simulated procedures } \\
\text { which enable faculty to } \\
\text { practice teaching skills } \\
\text { (micro-teaching) }\end{array}$ & 36 & 0 & 63 \\
\hline
\end{tabular}

*Percent based only on institutions at which practice existed. 
All ten assessment practices (Table 3) were used in Canadian universities. Seventy-two percent of the respondents indicated that over 20 percent of the faculty members at their institutions used systematic ratings of instruction by students, but only 21 percent perceived these ratings to be effective. Other practices commonly used included systematic evaluations by an administrator, and informal assessment by colleagues.

Respondents rated the professional and personal development plan (or growth contract) as the most effective practice in this group, although the practice was not used extensively. Other effective assessment practices included a system for self assessment, and classroom visitation by an instructional resource person. Assessment practices followed by some types of consultation appeared to be among the most effective for development purposes.

\section{Miscellaneous Practices}

Five miscellaneous practices are also reported in Table 3; none of them was used extensively in Canadian universities. Grants for faculty members to develop new or different approaches to courses or teaching were most used in this group, and this practice was perceived to be quite effective among those who used it.

The two most effective among the miscellaneous practices were personal counseling provided for individual faculty members, and faculty exchange programs with other institutions. Neither of these practices was used much in Canadian universities.

\section{Most Pressing Needs}

Respondents were asked to identify the most pressing development needs of faculty members at their institutions. The responses to this open-ended question varied considerably. Whereas some did not identify any pressing need, others mentioned more than one.

The most pressing development needs of faculty members in Canadian universities, as perceived by coordinators of development activities, were in the following areas. ${ }^{4}$

1. Instructional techniques and course development (11)

2. Recognition of effective teaching in reward system (6)

3. Personal and interpersonal skill development (5)

4. Continuing education in discipline area (4)

5. Assessment of educational development needs (3)

6. Funds for educational development (2)

7. Improved research opportunity (2)

8. Long range career development (2)

Clearly, the most frequently mentioned development needs were in the area of instructional and course development. Needs in the areas of organizational and

\footnotetext{
${ }^{4}$ The numbers in parentheses indicate the number of times needs were identified in this area.
} 
21 Faculty Development Practices in Canadian Universities

\section{Table 3}

Estimated Use and Effectiveness of Faculty Development Practices: Analyses or Assessment and Miscellaneous Practices

\begin{tabular}{c} 
Percent indicating use \\
Practice \\
Not used Over $20 \%$ \\
\hline
\end{tabular}

Analysis or assessment practices

\begin{tabular}{|c|c|c|c|}
\hline $\begin{array}{l}\text { Systematic ratings of } \\
\text { instruction by students }\end{array}$ & 12 & 72 & 21 \\
\hline $\begin{array}{l}\text { Systematic teaching or } \\
\text { course evaluation by an } \\
\text { administrator for improve- } \\
\text { ment purposes }\end{array}$ & 40 & 16 & 44 \\
\hline $\begin{array}{l}\text { Informal assessments by } \\
\text { colleagues }\end{array}$ & 12 & 12 & 25 \\
\hline $\begin{array}{l}\text { Faculty with expertise consult } \\
\text { with other faculty on } \\
\text { teaching or course improve- } \\
\text { ment }\end{array}$ & 4 & 8 & 31 \\
\hline $\begin{array}{l}\text { Formal assessments by } \\
\text { colleagues (e.g., visita- } \\
\text { tions) }\end{array}$ & 32 & 8 & 30 \\
\hline $\begin{array}{l}\text { System for faculty to assess } \\
\text { their own strengths and areas } \\
\text { needing improvement }\end{array}$ & 44 & 8 & 67 \\
\hline $\begin{array}{l}\text { Professional and personal } \\
\text { development plan (growth } \\
\text { contract) }\end{array}$ & 44 & 4 & 72 \\
\hline $\begin{array}{l}\text { Analysis of in-class video } \\
\text { tapes to improve instruction }\end{array}$ & 20 & 0 & 33 \\
\hline $\begin{array}{l}\text { Classroom visitation by an } \\
\text { instructional resource } \\
\text { person, upon request, } \\
\text { followed by a diagnosis }\end{array}$ & 40 & 0 & 60 \\
\hline $\begin{array}{l}\text { "Master teachers" or senior } \\
\text { faculty work closely with } \\
\text { new or apprentice teachers }\end{array}$ & 44 & 0 & 43 \\
\hline \multicolumn{4}{|l|}{ Miscellaneous practices } \\
\hline $\begin{array}{l}\text { Grants for faculty members to } \\
\text { develop new or different } \\
\text { approaches to courses or } \\
\text { teaching }\end{array}$ & 16 & 4 & 44 \\
\hline $\begin{array}{l}\text { Faculty take courses offered } \\
\text { by colleagues }\end{array}$ & 28 & 4 & 25 \\
\hline $\begin{array}{l}\text { Visits to other institutions } \\
\text { to review programs or } \\
\text { projects }\end{array}$ & 20 & 0 & 36 \\
\hline $\begin{array}{l}\text { Faculty exchange program with } \\
\text { other institutions }\end{array}$ & 40 & 0 & 50 \\
\hline $\begin{array}{l}\text { Personal counseling provided } \\
\text { individual faculty members } \\
\text { on career goals, and other } \\
\text { personal development areas }\end{array}$ & 48 & 0 & 60 \\
\hline
\end{tabular}

*Percent based only on institutions at which practice existed. 
personal development were second and third in this listing. The listing could serve as an agenda for development activities in universities, although a broaderbased survey should be undertaken to validate this listing.

\section{Most Effective Practices}

The second open-ended question invited respondents to identify the most effective practices at their institutions in helping faculty members achieve greater effectiveness in teaching. Forty-five responses were categorized as follows:

1. Workshops and seminars on instructional techniques (8)

2. Instructional development resource centre (6)

3. Professional consultation in teaching (6)

4. Systematic instructional evaluation procedures (6)

5. Informal colleague interaction on teaching (5)

6. Recognition of effective teaching in reward system (5)

7. Instructional development grants for faculty (4)

8. Miscellaneous: micro-teaching (3), newsletter (1), teaching day (1)

Most of these development practices focused upon instructional technology, either in a small group or an individual activity. Organizational development practices included the provision of a resource centre, systematic evaluation procedures, and recognition of effective teaching in the reward system.

A third question asked for additional activities that should be made to assist faculty members achieve greater effectiveness, but the responses were similar to the listing of most effective practices. Recognition of effective teaching in the reward system, systematic evaluation procedures, and a development resource centre were mentioned most frequently.

\section{Faculty Involvement}

The proportion of faculty members involved in development activities is shown in Table 4. Faculty members in each of the six categories were involved in some development activities.

Among the faculty members most involved in development activities were the good teachers who wanted to get better, followed closely by tenured faculty members. Younger faculty members in their first years of teaching were moderately involved, somewhat more than were faculty members with over 15 or 20 years of teaching experience.

By far the least involved in development activities were the faculty who really needed to improve. Although development activities generally are offered on a voluntary basis, they seem not to attract as many of those who need improvement and security as those who have already achieved a good measure of excellence and security. Perhaps what is needed is a reward system that incorporates more clearly the benefits derived from participation in development activities. 
Table 4

Estimated Involvement of Faculty Members

in Development Activities

\begin{tabular}{|c|c|c|c|c|c|}
\hline \multirow[b]{2}{*}{ Category } & \multicolumn{4}{|c|}{ Percent indicating involvement } & \multirow[b]{2}{*}{$\begin{array}{c}\text { No } \\
\text { Response } \\
\end{array}$} \\
\hline & $\begin{array}{l}\text { Very } \\
\text { Few }\end{array}$ & Some & $\begin{array}{l}\text { About } \\
\text { Half }\end{array}$ & Most & \\
\hline $\begin{array}{l}\text { Younger faculty in their } \\
\text { first years of } \\
\text { teaching }\end{array}$ & 8 & 52 & 12 & 16 & 12 \\
\hline $\begin{array}{l}\text { Faculty with over } 15 \text { or } \\
20 \text { years of teaching } \\
\text { experience }\end{array}$ & 16 & 56 & 8 & 4 & 16 \\
\hline Non-tenured faculty & 8 & 44 & 24 & 4 & 20 \\
\hline Tenured faculty & 0 & 56 & 16 & 22 & 16 \\
\hline $\begin{array}{l}\text { Faculty who really } \\
\text { need to improve }\end{array}$ & 44 & 24 & 4 & 0 & 28 \\
\hline $\begin{array}{l}\text { Good teachers who } \\
\text { want to get better }\end{array}$ & 0 & 24 & 4 & 0 & 28 \\
\hline
\end{tabular}

\section{Organization and Funding}

Of the institutions that responded to the survey, 68 percent reported having a person or unit for coordinating faculty development activities. (Since only $60 \%$ of all universities were included in this survey, it follows that only about $40 \%$ of the universities in Canada have any coordination of development activities.) Most of the persons who coordinate faculty development activities reported doing so on a part-time basis.

Faculty development programs are no longer new in many Canadian universities. They range in age from two to twelve years, with a median of six years.

The cost of development activities constitutes a major issue at many institutions. Indeed, recent cutbacks have severely curtailed programs in several universities.

Most of the financial support for faculty development is derived directly from institutional budgets. In most institutions, less than one percent of the budget was allocated to development activities. Only three institutions had received funds for faculty development from external sources.

Evaluation of faculty development programs was not common in Canadian universities. Fifty-two percent of the respondents reported no evaluation of any kind, and another 28 percent reported only partial evaluation. Clearly, development activities could be strengthened as a result of systematic evaluation. 


\section{CONCLUSIONS}

The purpose of this paper was to describe the nature and effectiveness of faculty development practices in Canadian universities. Data were drawn from a survey of coordinators of development activities in universities that had such practices.

1. Sixty percent of the universities had an organized program or a set of development activities. About two-thirds of these universities had a person or a unit for coordinating faculty development activities; most development staff persons served on a part-time basis in this role.

2. Traditional practices, like sabbatical leaves, travel funds to attend professional meetings, and circulation of newsletters and articles, were among the most common in faculty development. These institution-wide practices are designed to serve all faculty members equally, regardless of their level of expertise or status.

3. Some of the practices perceived to be most effective for development purposes were among the least used in Canadian universities. Although these activities were rated very highly, few faculty members participated in professional development activities during a specific calendar period, through professional growth contracts, systematic self-assessment, or micro-teaching clinics.

4. Workshops, assistance of specialists, and assessment practices were fairly common on many campuses, and were judged to be moderately successful. Activities that focused upon specific need areas appeared to be more effective than those that were of a general nature. Of course, there was no diagnostic information available in this survey to explain why some practices were perceived to be more effective than others.

5. In the view of coordinators, the most pressing development needs of faculty members in Canadian universities lie in the area of instructional improvement, rather than in personal or organizational development. To give priority to immediate, specific task areas in development activities, seems to be a pattern also experienced elsewhere (Harding et al, 1981). As faculty development "matures" within an institution, its range of activities may expand to address a wider array of professional interests.

6. The greatest involvement in development activities was on the part of "good teachers who want to get better," followed closely by tenured faculty members. Non-tenured staff, and especially faculty members "who really need to improve," were minimally involved in development activities. What accounts for this pattern of participation is open to conjecture. Perhaps the institutional climate or even the reward system undermine the quest for excellence, especially in teaching. Faculty development activities may be subject to scepticism and ruthless criticism on a campus, particularly if these activities lack commitment in the upper echelons of an institution. Neither will development activities succeed, it seems, if they are regarded as "tools of the administration." Individual growth is most likely to occur when a personal commitment for such development is made within a supportive professional climate. 
7. Faculty development activities are limited in their effectiveness, in part, because of their treatment as temporary systems in Canadian universities. Although "coordinators" for development activities exist in many universities, most of them serve on a part-time basis. Furthermore, resources appear to be too minimal for the development of adequate programs. As Gustafson (1977) maintained, too many institutions regard faculty development as a luxury, a frill which in hard times is difficult to maintain. As the experience of some universities indicates, faculty development was the last service to be added and the first to be cut. Finally, the absence of systematic evaluation and ongoing feedback for development activities undermines their effectiveness.

In conclusion, faculty development practices exist in many Canadian universities. Indeed, the array of practices is quite similar to that reported in a survey of colleges and universities in the United States (Centra, 1976). What is not evident, however, is the extent of institutional commitment and the impact of these practices in Canadian higher education. Faculty members constitute the most treasured resource of a university; their optimal development lies in the best interests of an institution's quest for excellence.

\section{REFERENCES}

Bergquist, W.H., \& Phillips, S.R. Components of an effective faculty development program. Journal of Higher Education, 1975, 46, 177-211.

Centra, J.A. Faculty Development Practices in U.S. Colleges and Universities. Princeton, New Jersey: Educational Testing Service, 1976.

Crow, M.L. et al., Faculty Development Centers in Southern Universities. Atlanta, Georgia: Southern Regional Education Board, 1976.

Gaff, J.G. Toward Faculty Renewal. San Francisco: Jossey-Bass, 1975.

Gustafson, K.L. Can you really do instructional development on two cents a day? Journal of Instructional Development, 1977, 1, 28-29.

Harding, A.G. et al., Professional Development in Higher Education: State of the Art \& the Artists. Bradford, England: University of Bradford Educational Development Service, 1981.

Morales, S., \& McGinn, N.F. Faculty development in Mexican universities. Journal of Higher Education, 1982, 53, 532-551.

Nelson, W.C. Faculty development: prospects and potential for the 1980 's. LiberalEducation, $1979,65,141-149$.

Sheffield, E.F. Teaching in the Universities: No one way. Toronto: McGill - Queen's University Press, 1974.

Shore, B.M. Instructional development in Canadian higher education. Canadian Journal of Higher Education, 1974, 4, 45-53.

Webb, J., \& Smith, A.B. Improving instruction in higher education. Educational Horizons, 1976, 55, 86-91. 